\title{
Does a country's openness to trade and capital accounts lead to financial development? evidence from Malaysia
}

\begin{abstract}
This paper examines the role of trade openness and capital account openness in influencing financial development in Malaysia. The empirical findings using the bounds testing approach demonstrate that trade openness and capital account openness are positively significant determinants of financial development. However, there is no empirical support of the hypothesis that the simultaneous opening of both trade and capital accounts is necessary for financial development to take place. The evidence is valid for three banking sector development and two stock market development indicators.
\end{abstract}

Keyword: Bounds test; Financial development; Financial openness; Trade openness 